Cambridge Archaeological Journal

http://journals.cambridge.org/CAJ

Additional services for Cambridge Archaeological Journal:

CAMBRIDGE

ARCHAEOLOGICAL

Email alerts: $\underline{\text { Click here }}$

Subscriptions: $\underline{\text { Click here }}$

Commercial reprints: $\underline{\text { Click here }}$

Terms of use : $\underline{\text { Click here }}$

\title{
Rethinking 'Cattle Cults' in Early Egypt: Towards a Prehistoric Perspective on the Narmer Palette
}

David Wengrow

Cambridge Archaeological Journal / Volume 11 / Issue 01 / April 2001, pp 91 - 104

DOI: 10.1017/S0959774301000051, Published online: 05 September 2001

Link to this article: http://journals.cambridge.org/abstract_S0959774301000051

How to cite this article:

David Wengrow (2001). Rethinking 'Cattle Cults' in Early Egypt: Towards a Prehistoric Perspective on the Narmer Palette.

Cambridge Archaeological Journal, 11, pp 91-104 doi:10.1017/S0959774301000051

Request Permissions : $\underline{\text { Click here }}$ 


\title{
Rethinking 'Cattle Cults' in Early Egypt: Towards a Prehistoric Perspective on the Narmer Palette
}

\author{
David Wengrow
}

\begin{abstract}
The Narmer Palette occupies a key position in our understanding of the transition from Predynastic to Dynastic culture in Egypt. Previous interpretations have focused largely upon correspondences between its decorative content and later conventions of élite display. Here, the decoration of the palette is instead related to its form and functional attributes and their derivation from the Neolithic cultures of the Nile Valley, which are contrasted with those of southwest Asia and Europe. It is argued that the widespread adoption of a pastoral lifestyle during the fifth millennium $B C$ was associated with new modes of bodily display and ritual, into which cattle and other animals were incorporated. These constituted an archive of cultural forms and practices which the makers of the Narmer Palette, and other Protodynastic monuments, drew from and transformed. Taking cattle as a focus, the article begins with a consideration of interpretative problems relating to animal art and ritual in archaeology, and stresses the value of perspectives derived from the anthropology of pastoral societies.
\end{abstract}

The notion that cattle occupied an important place in the early development of ritual and religious life in the Old World predates the systematic archaeological study of prehistory. Alongside those of the 'great mother goddess', cults of 'the bull' featured prominently in speculative prehistories of the late nineteenth century, such as those of Robertson Smith (1889), Frazer (1890), and Hahn (1896). Their ideas regarding what Robertson Smith termed the 'ancient holiness of cattle' derived from ancient Near Eastern and Graeco-Roman texts, and also from what were viewed as 'survivals' of ancient beliefs and practices among contemporary pastoral peoples.

In the course of the twentieth century, archaeological investigation revealed extensive evidence that cattle were, indeed, integrated into a wide array of prehistoric cultural practices. Many are central to our understanding of the major social transformations undergone in the Near East and surrounding regions from Neolithic to Bronze Age times, and beyond. Some of the better-known examples include the decorated houses of Çatalhöyük in central Turkey (Mellaart 1967; Todd 1978; Hodder 1990; 1996), the bucranium-adorned Halaf pottery of the northern arc of the Fertile Crescent (Mallowan \& Rose 1935; von Oppenheim 1943; Goff 1963), and model terracotta 'sanctuaries' from tombs of the Cypriot Early Bronze Age, such as that from Vounous which contains a ritual scene involving a figure with mixed human and cattle attributes (Morris 1985; Karageorghis 1991).

In spite of their importance as documents of cultural change, however, forms and images relating to cattle have often remained subject to cliché and generalization in archaeological interpretation. There has been a tendency to accord them a qualitatively different status from other, contemporaneous forms of prehistoric animal art; a legacy, perhaps, of earlier writings and traditional Western imaginings of the ancient world (e.g. Rice 1998). Cauvin, for instance, sees the complex development of cattlerelated imagery in the Near East from Neolithic to Bronze Age times as expressing a 'pensée mythique d'Orient et de Méditerranée', based around the interplay between primordial symbols of 'Woman' and 'Bull'. His postulated 'religion de taureau' stems from primeval and, he asserts, universal associations 
betweeen the bull and 'une force brute, instinctive et violente' (Cauvin 1994, esp. 44-52, 163-6). Also notable are recent attempts, some more explicit than others, to resurrect the idea of a distinctive northeast African 'Kulturkreis' (or 'culture-complex') based around the religious significance of cattle, from which the belief systems of both ancient Egypt and modern Nilotic cattle-keepers are held to have emerged (e.g. Schwabe 1994; Celenko 1996; Wendorf \& Schild 1998; Wilkinson 1999: Hamite/Hamitic). ${ }^{1}$ In view of this trend it seems imperative to stress that there is no historical evidence for a direct connection between modern Nilotic cattle-keepers and the ancient or prehistoric peoples of Egypt. The relationship between them was conceived within the context of racial, linguistic, and theological debates of the early twentieth century (Seligman 1914; 1932; 1934; Schmidt 1940).

It is not sufficient, however, simply to exorcise the 'cult of the bull' from archaeological discourse on the grounds of its datedness or spurious intellectual origins. A narrow materialist account of changing human attitudes towards the animal world during later prehistory, which discounts the rich symbolic culture associated with cattle, would be equally unrepresentative of the evidence.

\section{An anthropological perspective}

An alternative avenue of investigation has been proposed by Ingold (1994, 19). 'I am suggesting', he writes, 'that we rewrite the history of human-animal relations', taking a condition of 'active engagement, of being-in-the-world, as our starting point. We might speak of it as a history of human concern with animals, in so far as this notion conveys a caring, attentive regard, a "being with".' 'And I am suggesting', he goes on, 'that those who are "with" animals in their day-to-day lives, most notably hunters and herdsmen, can offer us some of the best possible indications of how we might proceed.'

Where ritual and symbolic treatments of cattle are concerned, prehistorians might therefore turn to the rich anthropological literature on religious life in pastoral societies. In doing so, I should stress that my own choice of ethnography is not influenced by geographical setting or assumed cultural continuity between ancient and modern peoples. I envisage the relationship between archaeology and anthropology in much the same way that Evans-Pritchard described that between anthropology and history in his 1961 lecture on the subject (Evans-Pritchard 1962, 46-65). Anthropology, he suggested, had an important role to play in freeing the interpretation of the past from perspectives rooted in the immediate social and cultural experience of the interpreters. In particular, the physical proximity of the field-anthropologist to living subjects raises questions that are unlikely to arise from the historian's purely mental and emotional encounter with textual sources (or, by extension, from that of the archaeologist with the material record of past thoughts and actions). The extent to which archaeologist and anthropologist may learn from one another's work therefore depends, first and foremost, upon the strength of relationship between the questions that each has asked of their respective material, and upon the quality of the answers they have provided.

This approach might seem archaic or even disingenuous, given the dense literature that appeared from the 1960s-80s on the practical and theoretical relationships between archaeology and anthropology (e.g. Binford 1962; Kramer 1979; Gould 1978; 1980; Hodder 1982; 1986). My problem with most of the approaches advocated there, however, is that they rest upon an unacceptable combination of archaeological pessimism (can we really reconstruct the past from its material remains?) and anthropological positivism (yes - but only according to principles of interpretation developed by observing living societies). Assertions about the archaeological record are held to gain in validity by being passed through a filter of ethnographic 'reality'; by implication an objective reality that few anthropologists would now aspire to: 'Notwithstanding the realist idiom of their craft, they widely accept that - like other forms of understanding - ethnography is historically contingent and culturally configured' (Comaroff \& Comaroff 1992, 9; see also Clifford \& Marcus 1986; Okely \& Callaway 1992). Given this, it seems preferable to return to a position similar to that outlined in 1969 by Peter J. Ucko: 'The primary use of ethnographic parallels . . . is simple. It is to widen the horizons of the interpreter ... the width of approach will make the archaeologist re-analyse his own material.' (Ucko 1969, 262-4; cf. Frankfort 1948a, 165, n.5; 1951, 21-2; Wengrow 1999, 606).

In his major work on Dinka religion, Divinity and Experience, Godfrey Lienhardt (1961) described cattle sacrifice at first hand. He characterized it as an extension of the act of exchange beyond the earthly realm, through which moral forces of the community were transposed from a human agent onto a bovine one. The role of the animal in absorbing negative influences and releasing them from their human victims was predicated upon the close identification of Dinka with their herds. This derived from the 
central place occupied by cattle in their daily lives, and from a range of social and cultural practices which reinforced the communicative role of cattle in the conduct of human affairs. $^{2}$ These included regular exchanges of cattle as the accepted form of bridewealth, as compensation for crimes, or as a means of perpetuating status across generations. In addition, an array of dances, praise songs, and other forms of personal and collective presentation emphasized this community of people and cattle (cf. Coote 1992). The performance of a sacrifice was therefore interpreted by Lienhardt as a vehicle for the expression of hu-
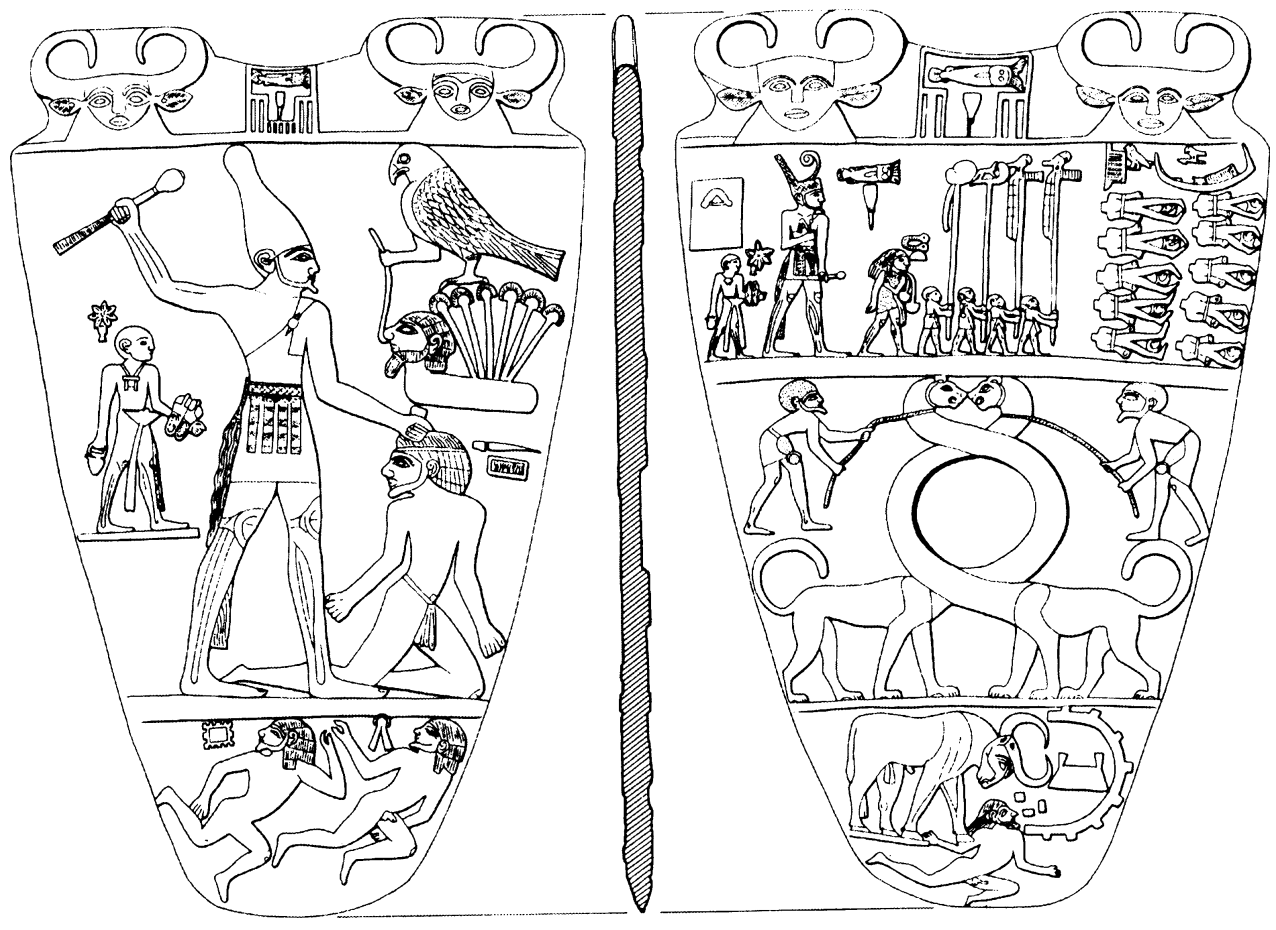
man concerns, rooted in real social dilemmas and deriving its cultural force from people's wider investment of interests and values in the lives of their herds.

Lienhardt's analysis of cattle sacrifice draws attention, by way of contrast, to the implausibility of a purely religious or psychological approach to this and related subjects, in a way that seems instructive for archaeological interpretation. Principally, it highlights the dangers of slipping into a discourse whereby animals, rather than people, are cast in the role of what Alfred Gell has termed 'primary agents':

Let me return to the distinction . . . between 'primary' agents (entities endowed with the capacity to initiate actions/events through will or intention) and 'secondary' agents, entities not endowed with will or intention by themselves but essential to the formation, appearance, or manifestation of intentional actions (Gell 1998, 36).

In suggesting that cattle were 'sacred' creatures, in Durkheim's sense of things set apart from temporal affairs and approachable only through acts of ritual and religious observance, we risk mystifying their place in the cultural development of the Old World during pre- and early historic times. All symbolic treatments of cattle then become manifestations of a single phenomenon - their purportedly strange and unexplained ability to exert an influence over hu-

man minds and actions. Forms and images relating to them are, in turn, artificially removed from the changing patterns of cultural expression, social interaction, and practical reason from which they arose, and which they could yet serve to inform.

\section{The Narmer Palette}

To appreciate the novelty of the design of the Narmer palette, we must investigate its antecedents. (Henri Frankfort 1951, 79)

In what follows I would like to consider the place of cattle as 'secondary agents' in the formation of Dynastic culture in the Nile Valley, taking as my focus one of the best-known artefacts of the ancient Old World. The Narmer Palette (Fig. 1) was discovered over a century ago at the site of Hierakonpolis in Upper Egypt (Quibell 1898). Over $60 \mathrm{~cm}$ in height, it is one of a series of elaborately carved, portable objects, dating to the formative period of Dynastic culture in Egypt - around the turn of the third millennium $\mathrm{BC}$ (the objects and current debates regarding their significance are reviewed by Baines 1995, with references). Other well-known examples include the Narmer Macehead, which depicts the presentation of cattle, goats, and human captives to 
a seated ruler (Millet 1990), the famous flint knife acquired near Gebel el-Araq, its decorated ivory handle showing a scene of combat (Mellink \& Filip 1974, Taf. 210), and a slightly later ivory comb bearing the name of a king of the First Dynasty (Frankfort 1948a, fig. 17).

As Frankfort $(1951,79)$ observed, the material and shape of the Narmer Palette 'proclaim it a specimen of a common type of toilet article' (cf. Baines $1995,110)$. On its obverse, an empty depression is left between the intertwined necks of two mythical creatures for the grinding of pigments, thereafter mixed into a coloured paste and applied to the body. This function was fulfilled by similar, but less ornate, stone palettes for some two thousand years prior to its creation. The ceremonial maces, knives, and combs of the Protodynastic period are also large and elaborate versions of common artefact types that first became widespread in the Nile Valley, along with cosmetic palettes, during the fifth and early fourth millennia BC (Badarian/Khartoum NeolithicNaqada I periods; see Petrie 1920; Baumgartel 1955; Kaiser 1964; Krzyzaniak 1991).

Most previous interpretations of the Narmer Palette have taken neither its function (or, for those who believe it was never actually used, the function to which its form refers) nor the extensive prehistoric background to its creation, into account. More commonly, the decorative content of the palette is abstracted from its material context, in the search for a self-contained message encapsulated within the imagery. The results of such an approach have been extremely diverse. Some have perceived a historical document of the unification of Upper and Lower Egypt (e.g. Asselberghs 1961; Emery 1961; Kaiser 1964), others a reflection of contemporaneous attitudes towards the cosmos (e.g. Baines 1989). What is generally agreed, however, is the importance of the Narmer Palette as an early and definitive manifestation of what became, in time, a standard mode of representation relating to Dynastic rulers in Egypt. The 'king smiting his enemies' remained an important motif throughout the Old, Middle, and New Kingdoms and into Roman times, when it was reproduced in monumental scale on the walls of temples (Hall 1986).

Returning to the scenes depicted on the object itself, we may note the various ways in which cattle are central to their arrangement and subject-matter. The top of the palette is decorated on both sides with carvings of a human face with bovine ears and horns, which stare directly out at the observer. These mixed human-cattle heads, like many Neolithic and Proto- dynastic images that suggest cattle-horns, have conventionally been interpreted as early manifestations of divinities known from Dynastic sources to have been represented with this attribute; i.e. the goddesses Bat and Hathor (e.g. Burgess \& Arkell 1958; Fischer 1962; Hornung 1982, 103; Williams 1988, 51; Winter 1994, 279; Wilkinson 1999). This use of later nomenclature is an inherently selective procedure, since many of the main zoomorphic subjects in Neolithic and Protodynastic art (e.g. fish and scorpion) are not ascribed similarly important positions to that of cattle in Dynastic representation. It therefore inhibits the understanding of that earlier art as a remnant of living modes of expression with their own coherence, leading us all too easily back to Sethe's (1930) proposition that animal imagery is somehow regressive and irrational (e.g. Goldwasser 1995, 14).

The mixed human-cattle heads frame a palace façade motif, or serekh, which contains hieroglyphs denoting the name of the main human protagonist. This figure is shown in two guises, which in later times came to represent the different sets of regalia associated respectively with rulership of Upper and Lower Egypt. Those features of his costume associated with cattle appear on the reverse, where he wears the White Crown of Upper Egypt and raises his mace in a smiting gesture. They include a bull's tail and a row of pendants suspended from his belt shaped to represent the head and horns of cattle, which later appear on a Third Dynasty statue of King Djoser from the Step Pyramid complex at Saqqara (Firth \& Quibell 1935, pl. 59).

On the obverse, the Red Crown is substituted for the White Crown, the mace is held below his waist, and his other hand grips a fly whisk as the ruler proceeds towards two lines of dismembered corpses belonging to defeated enemies. ${ }^{3}$ The latter are shown as living subjects on four occasions. They are easily identified, conforming to a stereotypical image perhaps intended to establish a paradigm of ugliness and uniformity, in opposition to the beauty and individuality of Narmer: a theme in keeping with the object's cosmetic associations. In the bottom register of the obverse the ruler's actions in subduing them are again represented, this time through the visual metaphor of a bull battering down the walls of an enclosure and trampling a foe. Decorated palettes of the same general period (see Petrie 1953; Asselberghs 1961; Davis 1992) show the ruler in other animal forms: as a bird of prey, scorpion, cobra, or lion. All are creatures that, like the bull, are capable of sudden and decisive action. This no doubt served 
to identify him with qualities of self-assertiveness, and the ability to render his opponents passive and helpless. On the reverse of the Narmer Palette his actions are also represented by a falcon with a human hand, usually associated with the god Horus (e.g. Baines 1989; 1995), which grasps a strip of land from which the head of a defeated enemy extends. The dual representation of the ruler's action in avian and bovine form is echoed in the substitution of cattle-head pendants for a single bird-shaped tag, attached to his belt, on the obverse of the palette.

Interpretations of the content of the Narmer Palette and other Protodynastic monuments have traditionally focused upon correspondences to later imagery and beliefs associated with kingship, and with the gods of Dynastic Egypt. Goldwasser's (1995, 5-6) recent summary of interpretative trends conveys well how the tendency to view the Narmer Palette teleologically (i.e. in terms of its relationship to some aspect of later Dynastic culture) has remained common to a wide range of otherwise diverse approaches: 'Art historians have long perceived it to be the first example of what is called in Egyptology "the canon of proportions and subjects" - that strict set of rules to which the main body of Dynastic art adheres' (see Iversen \& Shibata 1975, but also Robins' (1994) refutal; for comments on Egyptological uses of the term 'canonical', Baines 1989, 472). In the recent words of art historian Whitney Davis, 'The Narmer palette is the very site of the appearance of a new image; it is the very theatre in which the new scene of representation is being staged' (Davis 1992, 201). Scholars of religion, on the other hand, have emphasized the triumph of personified powers over those animalistic powers which dominated the prehistoric monuments such as the Two-dog Palette or the Hunter's Palette (Hornung 1982, 100-107). Finally, as a major historical testament, the palette has usually been taken to mark the unification of Egypt and the subduing of the Asiatic threat'. ${ }^{4}$

While Protodynastic monuments do, of course, exhibit important continuities with Dynastic culture, too direct an application of conventions and nomenclature derived from Dynastic sources may distort our understanding of these earlier images. In historical times the Egyptian gods are known to us through a system of what Hornung $(1982,117)$ has termed 'ideograms' or 'pictorial signs that convey meaning in a metalanguage'. They were not depicted iconically (i.e. as they were thought to look), but aspects of them were revealed through the interplay of hieroglyphic symbol and pictorial image, the canvas for which was the static surfaces of tomb and temple walls, and of frozen sculptures (cf. Frankfort 1948b). By contrast, the decorated palettes, maceheads, knives and combs of the Protodynastic period belong, by virtue of their form and scale, to a more intimate and animated realm of movement, interaction and display. They conveyed meaning at the level of close interpersonal contact and performance, drawing from and transforming an archive of established cultural practices that preceded them (cf. Winter 1994). In order to define more closely how these earlier practices and concepts relate to the development of the Narmer Palette, both in terms of its form and decorative content, it is necessary to place them within their wider prehistoric setting.

\section{Pastoralism and the prehistory of body decoration in the Nile Valley}

Recent reviews of osteological evidence for cattle domestication in northeast Africa suggest that domestic herds became widespread in the Nile Valley in the course of the late sixth and fifth millennia $\mathrm{BC}$ (Chenal-Vélardé 1997; Gautier 1987). This period is usually considered to have witnessed the inception of farming practices in the region, and hence the onset of the Neolithic period (Hassan 1988; Wetterstrom 1993). However, in contrast to the early farming communities of the Fertile Crescent which preceded them by some three thousand years, those of the Nile Valley show little sign of a village-based existence.

Where occupation sites dating to the fifth and early fourth millennia вС (Badarian/Khartoum Neolithic-Naqada I/Early A-Group) have been found, they typically consist of a series of superimposed deposits containing quantities of ash and cultural debris, sometimes associated with hearths and storage facilities, but with few traces of permanent architecture (e.g. Brunton \& Caton-Thompson 1928; Gabra 1930; Mond \& Myers 1937; Brunton 1937; 1948; Haaland 1987; Hendrickx \& Midant-Reynes 1988; Krzyzaniak 1991; see overview in Hassan 1988, 1545). Thick layers of animal droppings and remnants of ephemeral enclosures at many sites suggest that this pattern of deposition, documented on a far grander scale in the Neolithic ash-mounds of the Deccan plain in India, ${ }^{5}$ reflects the seasonal sojourns of mobile herding groups (cf. Butzer 1976, 14, 107; Hoffman 1972; 1982). ${ }^{6}$

This poverty of domestic culture contrasts with the richness of contemporary burial grounds, the known distribution of which is most dense in Upper Egypt and Central Sudan (references as in previous paragraph; see also Petrie \& Quibell 1896; Randall- 
MacIver \& Mace 1902; Ayrton \& Loat 1911; Geus 1991; Reinold 1991). Throughout much of the Nile Valley, from Middle Egypt to modern Khartoum, funerary rites took on a strikingly similar form during the fifth millennium $\mathrm{BC}$, suggesting a coherent and widely disseminated body of beliefs and practices. While the contents of particular interments differed, all appear to represent variations within a common form of mortuary practice, the characteristics of which may be broadly outlined. The individual was laid within an oval pit in a supine position, knees contracted and hands often cupping the face. The body was frequently wrapped in animal skins or reed mats and decorated with neck, arm and leg ornaments made of coloured stone beads, pierced shells, worked bone, tooth, and ivory: remnant vocabulary from a lost language of display which must have expressed occasions in the human lifecycle other than death alone. Around the body were placed salient artefacts of the social world. These typically included stone or ceramic maces, small pottery vessels, simple cosmetic palettes accompanied by grinding pebbles and pigments (sometimes found within leather pouches or small containers made of stone, ivory, or shell), and implements made of bone or ivory such as spatulas, hairpins, and combs (see Baumgartel 1960). Individuals, parted from the living group, were accompanied to the grave by those objects through which they had observed its selfimposed rules of consumption and presentation.

It is striking that nearly all of the items interred with the dead were designed to be easily carried by, or wearable on, the individual person, many relating directly to the decoration and ornamentation of the body. Most are provided with some means of suspension, either by perforation, incised grooves, or elaboration with decorative features that would have allowed attachment by a string or cord. Given the ephemerality of contemporary living sites, the cultural assemblage of early Neolithic communities in the Nile Valley therefore suggests a mobile, bodycentred habitus (Bourdieu 1977, 78), and it seems plausible that its appearance and dissemination was linked to the widespread adoption of a pastoral lifestyle during the fifth millennium вс. This pattern of life supplanted a relatively sedentary form of Mesolithic existence, based upon abundant aquatic resources, and archaeologically characterized by dense occupational deposits yielding large quantities of pottery and heavy grindstones (Caneva 1991; Haaland 1992; 1993).

Another feature of early Neolithic mortuary culture in the Nile Valley and adjacent regions was the interment of cattle, and other animals, in otherwise human cemeteries. At Badari, in Upper Egypt, the bodies of cattle were wrapped in matting and lowered into oval pits, undifferentiated from the human burials around them (Brunton \& Caton-Thompson 1928, 7-12, 38, pl. X.6), while at El Ghaba and Kadruka, in Central Sudan, the horns and crania of cattle were placed directly above the heads of human interments (Lecointe 1987; Reinold 1987; 1991). In the Western Desert, a number of stone-covered burials containing the remains of cattle have been found, lining the western edge of a major wadi running into Nabta Playa (Wendorf \& Schild 1998).

Burials of cattle or elements of cattle-bodies continue to be a feature of early-mid fourth-millennium BC (Naqada I-II and A-Group) cemeteries in Upper Egypt and Nubia, including Naqada (Petrie \& Quibell 1896, 20-26); Abadiya (Petrie 1901, 33); Khor Bahan (Reisner 1910, 138, Cemetery 17); El-Mahasna (Ayrton \& Loat 1911, 11); El-Amra (Randall-MacIver \& Mace 1902, 21); Naga ed-Deir (Lythgoe \& Dunham 1965, 53-4, 63, 100; fig. 21a:6, Cemetery N.7000); El-Gerza (Petrie et al. 1912, 7); Abusir el-Meleq (Scharff 1926, 14, 73); Gebelein (Farina 1929, cited in Donadoni Roveri 1990, 25); and Hierakonpolis, where the ribs of buried cattle were found 'encased in a dark organic substance', perhaps intended to preserve the bodies (Hoffman 1982, 55, Locality 6, Tomb 7). ${ }^{7}$ Subsequently, cattle burials (most with the heads removed) also formed part of the 'royal' A-Group cemetery at Qustul in Lower Nubia (Williams 1986, 16), and approximately three hundred pairs of cattle-horns, some of which had clearly been trained into attractive forms, ${ }^{8}$ were inserted into clay heads modelled on a raised bench surrounding one of the largest tombs of the First Dynasty at Saqqara (Emery 1961, 71, pls. 8 \& 9; Tomb No. 3504).

The range of species to which mortuary treatment was accorded in Predynastic times also included goat, dog and gazelle (e.g. Reisner 1910, Cemetery 17; cf. Smith 1991, 98; Brunton 1937, 90; 1948, 22; Mond \& Myers 1937, 12; Debono \& Mortensen 1988, 39-47; Midant-Reynes et al. 1996, 95), and at least one burial of an elephant, as well as a mixed human/dog burial, have recently been uncovered at Hierakonpolis (Adams 1998).

These practices seem important for an understanding of the cultural processes through which human relations with, and social representations of, the non-human world were transformed in the Nile Valley during Neolithic times. Their significance is thrown into relief by comparison with the parallel processes that accompanied the adoption of domes- 
ticated plants and animals in the early Neolithic of the Near East, and many parts of Europe. There, as Hodder (1990) has pointed out, houses provided a central symbolic locus through which economic transformations became encoded and objectified within networks of social meaning (see also Cauvin 1994; Watkins 1996; Wengrow 1998). The term 'domestication', etymologically linked to the house, serves to convey both cultural and biological aspects of this process. In the Nile Valley, however, there is little evidence that domestic ritual played any role in restructuring human conceptions of the non-human world during the crucial period of the fifth millennium $\mathrm{BC}$. The evidence suggests, rather, that the adoption of a herding lifestyle was associated, over the long-term, with the introduction of new forms of rites de passage, visible to us only as they pertained to death, and that the primary vehicle for their articulation was not the house, but the bodies of people and animals. Hence, in applying the term 'domestication', an inappropriate metaphor is evoked. The cultural idiom of Neolithic transformation in the Nile Valley might be better characterized, perhaps, as an incorporation.

I have deliberately avoided equating these cultural transformations fully with the process of biological domestication in animals. As J. Desmond Clark (1971), among others, has pointed out, Old and Middle Kingdom pictorial sources reveal that even in much later times the practice of animal keeping was not restricted to those species that were genetically responsive to it. He therefore suggested that Neolithic processes of animal domestication in the Nile Valley had formed part of a broader shift towards the capturing and taming of animals, which is reflected in the decoration of Naqada I (C-Ware) pottery and in contemporary rock carvings of the Eastern Desert and Lower Nubia. Widespread biological domestication in cattle seems likely to have been just one aspect of more encompassing practical and conceptual changes in human-animal relations, and the evidence of Neolithic art and ritual testifies to the ongoing cultural importance of biologically 'wild' species during the Naqada I and II periods (cf. Finkenstaedt 1980).

It seems clear, then, that many of the cultural forms, ideas, and practices upon which the creators of the Narmer Palette and other ceremonial items of the Protodynastic period drew, were already a feature of Nilotic culture by the fifth millennium вс. During the fourth millennium, the cultural uniformity of the Nile Valley came to an end. This growing disparity followed related developments in water transport and cereal cultivation, which gave new salience to the geophysical diversity of the valley. South of Aswan, cataracts limited the impact of papyrus and wooden boats (Landström 1970), which gradually transformed the pace of life on the Egyptian Nile where they could sail, relatively unhindered, from Elephantine to the Mediterranean coast. ${ }^{9}$ People gravitated in increasing numbers to nodal points along the main arteries of riverine interaction in Upper Egypt (Trigger 1983). It may be at this juncture (roughly the Naqada I-II transition) that cereal farming began to play a decisive role in Egypt's development, providing opportunities for long-term occupation at key points of contact between the Nile Valley and its resource-rich hinterlands (cf. Majer 1992, 230).

Cultivated cereal grains are found in abundance at early fourth-millennium sites in the Naqada and Armant regions (Wetterstrom 1993), in the BadariHammamiya area (Brunton \& Caton-Thompson 1928, 62, 77; Brunton 1937, 90; 1948, 22), and at Hierakonpolis (El Hadidi 1982). Ongoing work at the latter site has greatly enhanced our understanding of the cultural changes that accompanied this new emphasis on cereal farming. Hoffman (1982) pointed out that, in addition to its accessibility, the Naqada II settlement at Hierakonpolis was favoured with an adjacent area of extended pasturage created by the neighbouring Wadi Abul Suffian, which generated 'a well watered pocket of biomass in the desert borderlands'. Other features at the site suggest an attempt to combine the maintenance of herds with increased sedentism, probably through an increase in artificial feeding with cultivated grain. ${ }^{10}$ They include the 'barnyardlike' enclosures of Locality 29 (subphase B), and the mud-brick stall traversed by two troughs at Locality 11, adjacent to the Wadi Abul Suffian, next to which was found a large basin containing spikelets of barley. At Locality 3, some $3 \mathrm{~km}$ west of the main floodplain settlement, twelve 'hut circles' were discovered, and were interpreted by the excavator as a 'herding station' (Hoffman 1982).

Despite these changing patterns of interaction, productive life, and occupation, the development of material culture in Upper Egypt proceeded largely along lines laid down in the preceding millennium. This is particularly clear in the increasingly complex mortuary rites accorded to both people and animals, and in evolving codes of self-presentation (see Midant-Reynes 1992, 163-216). During the Naqada I and II periods cosmetic palettes, combs and hairpins were increasingly decorated with figurative carvings, amongst which horned animals and birds were 


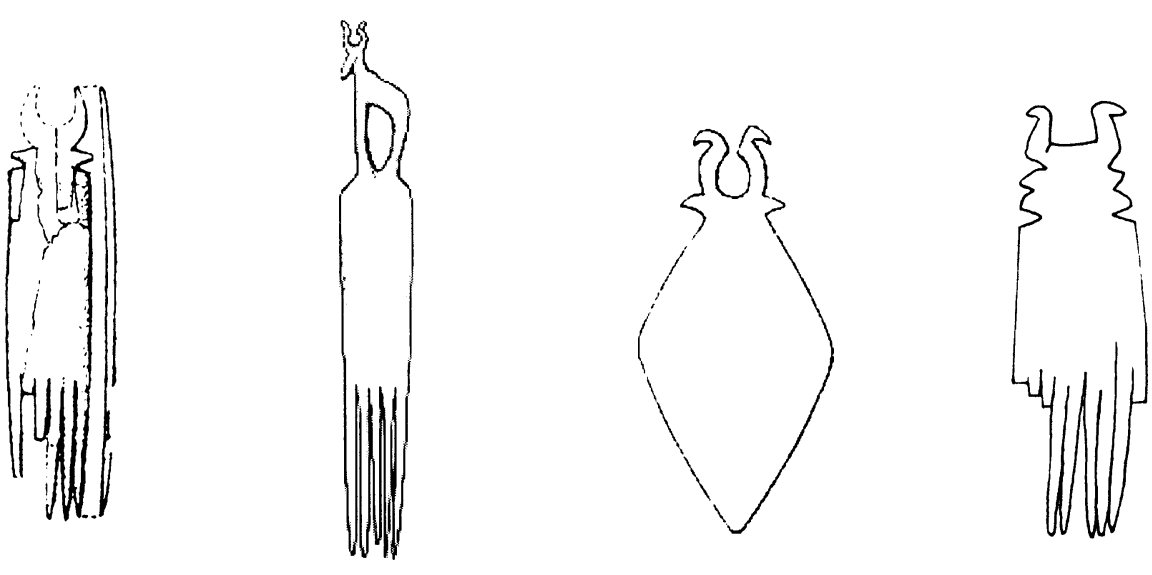

Figure 2. Cosmetic implements from Neolithic graves. (After Brunton 1937, pl. LXII:47; Payne 1993, fig. 77:1904; Quibell 1904-5, pl. 45:14172; Petrie 1920, pl. XXIX:10; scale approx. 1:3.)

common subjects, as well as other animals such as fish and turtles (see Petrie 1921; Cialowicz 1991). Preference for decorative forms which combined desired visual qualities with a means of fixing the object to the body seems to have been a factor in the development of animal ornament on Neolithic cosmetic implements (Fig. 2; Wengrow, in progress; cf. Baumgartel 1960). They formed part of the technology of personal display, not merely through their practical functions in paint-preparation and grooming, but also through their very appearance when worn. This fluidity between decorative form and function is vividly illustrated by a well-preserved female burial excavated at Abadiya (Petrie 1901, 34, pl.VI, grave B378); projecting from her hair were two pins ornamented with birds, and the functional ends of an undecorated spoon and comb.

As Baumgartel $(1960,52,86)$ noted, carved designs on cosmetic implements often appear to play upon a morphological ambiguity between avian and bovine forms (Fig. 2). Fusion of human, avian, and bovine attributes may also be characteristic of contemporary clay figurines that were sometimes interred with the dead. The well-known example shown at the far right of Figure 3 has a clearly female, anthropomorphic upper body, but its head is more beak-like than human, and its arms, like those of the figurines shown alongside it, curve upwards in a gesture perhaps evoking horns. ${ }^{11}$ This distinctive arm posture, which appears on fragments of a (?Naqada I) painted linen composition from Gebelein (Scamuzzi 1965, pl. 1), is also depicted on painted pottery of the Naqada I and II periods (e.g. Hendrickx 1998, figs. 5-6; Needler 1984, 76, fig. 1; Payne 1993, fig. 40:861), and in contemporaneous ${ }^{12}$ rock art of the
Eastern Desert. There, similar figures are often shown aboard boats, the prows of which were frequently adorned with designs resembling the horns of cattle and other animals (Červíček 1974, Types IV and V; note also the detailed carvings of boats with horned prows on a Dynasty I ivory tag and on the Gebel elArak knife handle, both illustrated by Landström 1970, figs. 18 \& 76).

These developments in representation and display have often been characterized in purely symbolic or religious terms, divorced from the material realities of state formation on the Nile, which are thought to have had an agrarian basis (e.g. Hassan 1988; 1992; Wilkinson 1999; cf. Fairservis 1989). Such an interpretation seems to rest upon an artificial divide between linked processes of conceptual and economic change which led to the emergence of Dynastic culture. While cereal farming undoubtedly played a vital role in this process, it was earlier changes in human-animal relations during the late sixth and fifth millennia $\mathrm{BC}$ that initially created a setting in which, as Comaroff \& Comaroff $(1992,130)$ wrote of another time and place, cattle increasingly 'entered into the making of persons and things, relations and statuses'. Alongside a variety of other animals, they presented themselves to their human predators, keepers, and protectors, not as sacred to profane, but as a salient part of the social and practical environment in which Dynastic culture took form. Their incorporation into Predynastic practices relating to death and personal display is significant because it suggests a more pervasive investment of human values in cattle than is implied by the term 'cult'; an investment that seems likely to have been woven into the political and economic, as well as spiritual, aspects of social life.

The Narmer Palette marks the historical limits of creativity within the cultural parameters established during these preceding millennia. Encapsulating potent symbols and practices of earlier times, ${ }^{13}$ it also placed them beyond the realm of concrete action in which they originated, consigning them instead to the domains of representation and rhetoric. This signifies a wider realization that the social agency of some individuals could no longer be suffi- 


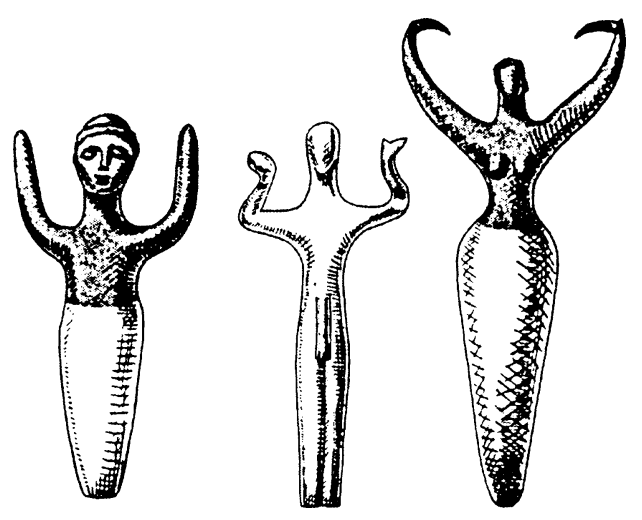

Figure 3. Neolithic clay figurines. (After Kantor 1944, fig.7:k, $n, 0$; scale approx. 1:6.)

ciently expressed within the temporal and spatial confines of embodied action and influence. As Groenewegen Frankfort (1951, 19-21) observed, 'from the Narmer Palette coincidence and contiguity are barred and the king's more violent gesture has therefore the peculiar static quality of a symbol. King Narmer's is a timeless act'. Within centuries of its creation, Egypt had witnessed the establishment of an élite world in which personal achievements, statuses, rights, expectations, and obligations - the raw materials of social identity - could be encoded in sculpture, painting, and script, and reproduced within the enduring and static structures of temples and tombs.

\section{Acknowledgements}

Earlier versions of this article were presented at seminars in the Universities of Oxford and London, and the final product owes much to the ensuing discussions. I would like to thank the various organizers for inviting me to speak: Nicola Schreiber, Corinna Riva and John Wilkins, Wendy James and Douglas Johnson, Angela McDonald and Christina Riggs. John Baines and Roger Moorey read earlier drafts and made many valuable comments and corrections, as did Andrew Sherratt who drew my attention to the Deccan ash-mounds. David $\mathrm{O}^{\prime}$ Connor was kind enough to let me read as yet unpublished work on the context and function of ceremonial palettes. I am also grateful to Jeremy Coote for forcing me to rethink the use of ethnographic sources, and to Thomas Kiely for information relating to the Aegean. My research for this year is funded by the British Academy Humanities Research Board, and by St Hugh's College (Oxford University).

\section{Notes}

1. Wendorf \& Schild (1998) cite Herskovits (1926) as a source for their notion of an African 'cattle complex' extending from prehistoric to recent times. Herskovits himself, however, restricted his observations to modern East Africa, noting that the 'cattle complex' was 'superimposed on what appears to be an underlying agricultural culture which may have preceded it historically'. For recent comment upon Herskovits' 'cattle complex' see Mair (1985), who refers to it as a 'mouldering cliché'.

2. For further ethnographic and historical studies of the social functions of animals in pastoral societies, see Evans-Pritchard (1940), Burton (1978), Comaroff \& Comaroff (1992), and also studies of non-African pastoralists (not necessarily cattle-keepers) such as Layard (1942), Jones (1974), Tapper (1979), Strathern (1971), and Walker (1986).

3. Davies \& Friedman (1998) have recently pointed out that both the heads and penises of the dismembered figures lie between their legs, except in the case of the lowest body in the first row, which is shown with the penis still attached.

4. Goldwasser's own approach, in treating the Narmer Palette as a 'purposeful linguistic construct', entirely divorces its symbolic meaning from its attributes as an artefact.

5. Dotted throughout the central part of the Deccan are immense mounds formed by superimposed strata of ash, chemically shown to be the product of burned cow dung, and packed soil containing cultural remains. Many excavated mounds have yielded evidence of livestock enclosures in the form of post-hole settings, and also frequent finds of cattle bones. The largest, at Kudatini, reached a diameter of 100-150 feet and a height of 25-40 feet (Allchin 1963; Paddaya 1973). For cattle-keepers, such mounds may take on a significance analogous to that of the mud-brick 'tells' formed by repeated superimposition of houses in traditionally constructed Middle Eastern villages (Kramer 1982), forming monuments to the productive relationship between people and the landscape. Burton (1980, 275), for instance, decribes how 'Atuot [Nilotic cattle-pastoralists occupying the eastern Lakes Province of southern Sudan] ox songs often include reference to the quantity of burnt cow dung ash (apuo) found underneath the shelter of one's family in a camp, suggesting and at the same time boasting of a long and prosperous period of residence at the camp'.

6. Clark (1971, 36) noted of Badarian occupation sites that 'The circle of grain pits surrounding a central area of ash and pottery suggests a plan similar to that of the Nilotic, cattle-herding Jie in Uganda, the Songhai south of the Niger bend and other central African peoples where a central stock pen is surrounded by the grain stores and temporary or permanent dwellings of the inhabitants.' 
7. An anonymous $C A J$ referee informs me that Oliver Myers also found an early cattle cemetery at Armant, though this is still not properly published.

8. The deformation of animal horns into elaborate shapes is a practice followed by herders all over the world (Coote 1992, 253), and is achieved by cutting the horns at a desired angle while the animal is young, such that they grow back against the cut (cf. Lienhardt 1961, 16; Deng 1972, 78-80).

9. Early evidence for the use of boats on the Nile is provided by the decoration of (Naqada I) White Crosslined pottery (C-Ware). One boat-shaped dish, for example, is decorated on its interior with a bird's eye view of a vessel with two reed cabins, propelled by paddles and bearing what appear to be horns on the stern and prow (Petrie 1920, pl. 15, 49; cf. Landström 1970). The same kind of boat is painted in profile on the inside of another C-Ware vessel from Gebelein, in association with a swirling arrangement of animal and abstract forms (Petrie 1920, pl. 23, 2; see Landström 1970 for further examples and discussion).

10. Lewis Henry Morgan's $(1877,24)$ speculation that 'Horticulture seems to have originated more in the necessities of the domestic animals than in those of mankind' may yet turn out to contain a grain of truth, for the Nile Valley at least.

11. This possibility was first intimated by Murray (1956, 92) and has since been more forcefully suggested by Červíček (1974), who terms it 'die Geste des Kuhtanzes' with reference to rock art; by Williams $(1988,51)$ with reference to its appearance on decorated pottery; and by Hassan $(1992,314)$. The figurine on the far right of Figure 3 is one of eighteen excavated by de Morgan at El Ma'mariya, and is dated to Naqada Ila by Needler $(1984,92)$. The central figurine is of unclear provenance, but the form of its lower body is very close to that of Needler's (1984) cat.no.274, the antiquity of which has been verified by thermoluminescence dating. That on the far left is thought to come from an excavated context at Khizam, the site of a cemetery dating from Naqada I to early Dynastic times (see Ucko \& Hodges 1963, 207). It may be significant that Predynastic cattle figurines (Randall-MacIver \& Mace 1902, pl. IX; Scharff 1929, Taf. 13:60; Payne 1993, fig. 14:56) frequently have beak-like heads similar to those of some anthropomorphic figurines, reinforcing the possibility of a deliberate ambiguity in the representation of these various kinds of animal, perhaps intended to express some form of relationship between them.

12. For the cross-dating of petroglyphs and painted pottery see Resch (1967) and Červíček (1974). There are particularly strong relationships between the visual style and subject matter of images painted in bold chalky outline on Naqada I White Cross-lined ware, and rock art of the Eastern Desert and Nubia (cf. Berger 1992, with references).

13. This is not to exclude the influence of external (Near Eastern) contacts upon the decoration of the Narmer
Palette, and upon other aspects of pre- and Protodynastic culture. The central design on the palette's obverse, showing felines with intertwined, serpent-like necks, appears as a motif on fourth-millennium $\mathrm{BC}$ cylinder seals of Mesopotamian origin, and it is likely that glyptic art, through its practical association with trade, provided a major channel for the incorporation of Mesopotamian and Susan conventions and motifs into the cultural vernaculars of surrounding regions (Frankfort 1951, 100-111; and, more recently, Smith 1992). This influence has been most widely discussed in relation to Egypt, but is also evident in the material culture of other regions on the margins of the 'Uruk Expansion', such as the Caucasus, where it is attested in the iconography of silver vessels from the Maikop 'royal tomb' (Sherratt 1997).

David Wengrow
St Hugh's College
Oxford University
Oxford
OX2 6LE

\section{References}

Adams, B., 1998. Something very special down in the élite cemetery. Nekhen News 10, 3-4.

Allchin, F.R., 1963. Neolithic Cattle-keepers of South India: a Study of the Deccan Ashmounds. Cambridge: Cambridge University Press.

Asselberghs, H., 1961. Chaos en Beheersing: documenten uit aeneolithisch Egypte. (Documenta et Monumenta Orientis Antiqui 8.) Leiden (NY): E.J. Brill.

Ayrton, E.R. \& W.L.S. Loat, 1911. Pre-dynastic Cemetery at El Mahasna. (Egypt Exploration Fund Memoirs 31.) London: Egypt Exploration Fund.

Baines, J., 1989. Communication and display: the integration of early Egyptian art and writing. Antiquity 63, 471-82.

Baines, J., 1995. Origins of Egyptian kingship, in Ancient Egyptian Kingship, eds. D.B. O'Connor \& D.P. Silvermann. Leiden (NY): E.J. Brill, 95-148.

Baumgartel, E., 1955. The Cultures of Prehistoric Egypt. Oxford: Oxford University Press.

Baumgartel, E., 1960. The Cultures of Prehistoric Egypt, vol. II. Oxford: Oxford University Press.

Berger, M.A., 1992. Predynastic animal-headed boats from Hierakonpolis and southern Egypt, in Friedman \& Adams (eds.), 107-20.

Binford, L.R., 1962. Archaeology as anthropology. American Antiquity 28, 217-25.

Bourdieu, P., 1977. Outline of a Theory of Practice. Translated by R. Nice. Cambridge: Cambridge University Press.

Brunton, G., 1937. Mostagedda and the Tasian Culture. British Museum Expeditions to Middle Egypt 1928, 1929. London: Quaritch.

Brunton, G., 1948. Matmar. British Museum Expeditions to 
Middle Egypt, 1929-31. London: Quaritch.

Brunton, G. \& G. Caton-Thompson, 1928. The Badarian Civilization and Prehistoric Remains Near Badari. (British School of Archaeology in Egypt and Egyptian Research Account 46.) London: Quaritch.

Burgess, E.M. \& A.J. Arkell, 1958. The reconstruction of a Hathor bowl. Journal of Egyptian Archaeology 44, 611.

Burton, J.W., 1978. Ghost Marriage and the cattle trade among the Atuot of the Southern Sudan. Africa 48(4), 398-405.

Burton, J.W., 1980. The village and the cattle camp: aspects of Atuot religion, in Explorations in African Systems of Thought, eds. I. Karp \& C.S. Bird. Bloomington (IN): Indiana University Press, 268-97.

Butzer, K.W., 1976. Early Hydraulic Civilization in Egypt: a Study in Cultural Ecology. Chicago (IL): University of Chicago Press.

Caneva, I., 1991. Prehistoric hunters, herders and tradesmen in Central Sudan: data from the Geili region, in Davies (ed.), 6-15.

Cauvin, J., 1994. Naissance des divinités. Naissance de l'agriculture. La Révolution des Symboles au Néolithique. Paris: CNRS Éditions.

Celenko, T., 1996. Egypt in Africa. Indianapolis (IN): Indianapolis Museum of Art.

Červíček, P., 1974. Felsbilder des Nord-Etbai, Oberägyptens und Unternubiens. Wiesbaden: Franz Steiner Verlag GMBH.

Chenal-Vélardé, I., 1997. Le boeuf domestique en Afrique $\mathrm{du}$ Nord, in Animals and People in the Holocene of North Africa, ed. A. Gautier. (Archaeozoologica IX/ 1.2.) Grenoble: Éditions La Pensée Sauvage.

Cialowicz, K.M., 1991. Les palettes égyptiennes aux motifs zoomorphes et sans décoration: étude de l'art prédynastique. Krakow: Uniwersytet Jagiellonski.

Clark, J.D., 1971. A re-examination of the evidence for agricultural origins in the Nile Valley. Proceedings of the Prehistoric Society 37, 34-79.

Clifford, J. \& G.E. Marcus, 1986. Writing Culture: the Poetics and Politics of Ethnography. Berkeley (CA): University of California Press.

Comaroff, J. \& J. Comaroff, 1992. Ethnography and the Historical Imagination. Oxford: Westview Press.

Coote, J., 1992. 'Marvels of everyday vision': the anthropology of aesthetics and the cattle-keeping Nilotes, in Anthropology, Art, and Aesthetics, eds. J. Coote \& A. Shelton. Oxford: Clarendon Press.

Davies, W.V. (ed.), 1991. Egypt and Africa: Nubia from Prehistory to Islam. London: British Museum Press in association with the Egypt Exploration Society.

Davies, W.V. \& R. Friedman, 1998. The Narmer Palette: a forgotten member. Nekhen News 10, 22.

Davis, W., 1992. Masking the Blow: the Scene of Representation in Late Prehistoric Egyptian Art. Berkeley (LA): University of California Press.

Debono, F. \& B. Mortensen, 1988. The Predynastic Cemetery at Heliopolis. Season March-September 1950. Mainz am Rhein: Philip von Zabem.
Deng, F.M., 1972. The Dinka of the Sudan. New York (NY): Holt, Reinhart \& Winston.

Donadoni Roveri, A., 1990. Gebelein, in Beyond the Pyramids: Egyptian regional art from the Museu Egizio, Turin, ed. G. Robins. Atlanta (GA): Emory University Museum of Art and Archaeology; Museo Egizio di Torino.

El Hadidi, N., 1982. The Predynastic flora of the Hierakonpolis region, in Hoffman (ed.), 102-15.

Emery, W.B., 1961. Archaic Egypt. Harmondsworth: Penguin Books.

Evans-Pritchard, E.E., 1940. The Nuer: a Description of the Modes of Livelihood and Political Institutions of a Nilotic People. Oxford: Clarendon Press.

Evans-Pritchard, E.E., 1962. Anthropology and history, in Essays in Social Anthropology, by E.E. Evans-Pritchard. London: Faber \& Faber, 46-65.

Fairservis, W., 1989. Cattle and archaic Egypt. The Review of Archaeology 10, 5-9.

Finkenstaedt, E., 1980. Regional painting style in prehistoric Egypt. Zeitschrift für Ägyptische Sprache und Altertumskunde 107, 116-20.

Firth, C.M. \& J.E. Quibell, 1935. The Step Pyramid. Cairo: Impr. de l'Institut Français d'Archéologie Orientale.

Fischer, H.G., 1962. The cult and nome of the Goddess Bat. Journal of the American Research Center in Egypt 1, 723.

Frankfort, H., 1948a. Kingship and the Gods. Chicago (IL): University of Chicago Press.

Frankfort, H., 1948b. Ancient Egyptian Religion: an Interpretation. New York (NY): Columbia University Press.

Frankfort, H., 1951. The Birth of Civilization in the Near East. Bloomington (IN): Indiana University Press.

Frazer, J.G., 1890. The Golden Bough: a Study in Comparative Religion. London: Macmillan.

Friedman, R. \& B. Adams (eds.), 1992. The Followers of Horus: Studies Dedicated to Michael Allen Hoffman. (Egyptian Studies Association Publication 2; Oxbow Monograph 20.) Oxford: Oxbow.

Gabra, S., 1930. Fouilles de Service des Antiquités à Deir Tasa. Annales du Service des Antiquités de l'Egypte 30, 147-58.

Gautier, A., 1987. Prehistoric men and cattle in North Africa: a dearth of data and a surfeit of models, in Arid North Africa: Essays in Honor of Fred Wendorf, ed. A.E. Close. Dallas (TX): Southern Methodist University Press, $163-87$.

Gell, A., 1998. Art and Agency: an Anthropological Theory. Oxford: Clarendon Press.

Geus, F., 1991. Burial customs in the Upper Main Nile: an overview, in Davies (ed.), 57-73.

Goff, B.L., 1963. Symbols of Prehistoric Mesopotamia. New Haven (NJ): Yale University Press.

Goldwasser, O., 1995. From Icon to Metaphor: Studies in the Semiotics of the Hieroglyphs. (Orbis Biblicus et Orientalis 142.) Fribourg, Göttingen: Vandenhoeck \& Ruprecht, University Press.

Gould, R.A. (ed.), 1978. Explorations in Ethnoarchaeology. Albuquerque (NM): University of New Mexico Press. 
Gould, R.A. (ed.), 1980. Living Archaeology. Cambridge: Cambridge University Press.

Groenewegen Frankfort, H.A., 1951. Arrest and Movement: an Essay on Space and Time in the Representational Art of the Ancient Near East. London: Faber \& Faber.

Haaland, R., 1987. Socio-economic Differentiation in the Neolithic Sudan. (BAR International Series 350, Cambridge Monographs in African Archaeology 20.) Oxford: BAR.

Haaland, R., 1992. Fish, pots and grain: early and midHolocene adaptations in the Central Sudan. African Archaeological Review 10, 43-64.

Haaland, R., 1993. Aqualithic sites of the Middle Nile. Azania 28, 47-86.

Hahn, E., 1896. Die Haustiere und ihre Beziehungen zur Wirtschaft des Menschen. Berlin: Duncker \& Humblot.

Hall, E.S., 1986. The Pharaoh Smites his Enemies: a Comparative Study. (Münchner Ägyptologische Studien 44.) Munich: Deutscher Kunstverlag.

Hassan, F., 1988. The Predynastic of Egypt. Journal of World Prehistory 2, 136-85.

Hassan, F., 1992. The mythogenesis of power in the early Egyptian state, in Friedman \& Adams (eds.), 30722.

Hendrickx, S., 1998. Peaux d'animaux comme symboles prédynastiques. À propos de quelques représentations sur le vase White Cross-lined. Chronique d'Égypte 53, 203-30.

Hendrickx, S. \& B. Midant-Reynes, 1988. Preliminary report on the Predynastic living site Maghara 2 (Upper Egypt). Orientalia Lovaniensia Periodica 19, 5-16.

Herskovits, M.J., 1926. The cattle complex in East Africa. American Anthropologist 28, 230-72, 361-88, 494-528, 633-64.

Hodder, I., 1982. The Present Past: an Introduction to Anthropology for Archaeologists. London: Batsford.

Hodder, I., 1986. Reading the Past: Current Approaches to Interpretation in Archaeology. Cambridge: Cambridge University Press.

Hodder, I., 1990. The Domestication of Europe. Oxford: Blackwell.

Hodder, I. (ed.), 1996. On the Surface: Çatalhöyük 1993-95. (McDonald Institute Monograph; British Institute of Archaeology at Ankara Monograph 22.) Cambridge \& London: McDonald Institute for Archaeological Research \& British Institute of Archaeology at Ankara.

Hoffman, M., 1972. Occupational features at Kom elAhmar: test excavations at locality 14 . Journal of the American Research Center in Egypt 9, 35-66.

Hoffman, M. (ed.), 1982. The Predynastic of Hierakonpolis an Interim Report. (Egyptian Studies Association 1.) Oxford: Alden Press.

Hornung, E., 1982 [1971]. Conceptions of God in Ancient Egypt: the One and the Many (translated by J. Baines). London: Routledge \& Kegan Paul.

Ingold, T., 1994. From trust to domination: an alternative history of human-animal relations, in Manning \& Serpell (eds.), 1-22.
Iversen, E. \& Y. Shibata, 1975. Canon and Proportions in Egyptian Art. 2nd edition. Warminster: Aris \& Phillips.

Jones, S., 1974. Men of Influence in Nuristan: a Study of Social Control and Dispute Settlement in Waigal Valley, Afghanistan. London: Seminar Press.

Kaiser, W., 1964. Einige Bemerkungen zur ägyptischen Frühzeit III. Die Reichseinigung. Zeitschrift für Ägyptische Sprache 91, 86-125.

Kantor, H., 1944. The final phase of Predynastic culture. Gerzean or Semainean. Journal of Near Eastern Studies 3, 110-36.

Karageorghis, V., 1991. The Coroplastic Art of Ancient Cyprus. Nicosia: A.G. Leventis Foundation.

Kemp, B.J., 1989. Ancient Egypt: Anatomy of a Civilization. London: Routledge.

Kramer, C. (ed.), 1979. Ethnoarchaeology: Implications of Ethnography for Archaeology. New York (NY): Columbia University Press.

Kramer, C., 1982. Village Ethnoarchaeology: Rural Iran in Archaeological Perspective. New York (NY): Academic Press.

Krzyzaniak, L., 1991. Early farming in the Middle Nile Basin: recent discoveries at Kadero (Central Sudan). Antiquity 65, 515-32.

Landström, B., 1970. Ships of the Pharaohs: 4000 Years of Egyptian Shipbuilding. London: Allen \& Unwin.

Layard, J., 1942. Stone Men of Malekula: Vao. London: Chatto \& Windus.

Lecointe, Y., 1987. Le site néolithique d'El Ghaba: deux années d'activité (1985-86). Archéologie du Nil Moyen 2, 69-87.

Lienhardt, G., 1961. Divinity and Experience: the Religion of the Dinka. Oxford: Clarendon Press.

Lythgoe, A.M. \& D. Dunham, 1965. The Predynastic Cemetery N7000, Naga-ed-Dêr, part IV. Berkeley (CA): University of California Press.

Mair, L., 1985. The cattle complex. Correspondence to Man 20(4), 743.

Majer, J., 1992. The eastern desert and Egyptian prehistory, in Friedman \& Adams (eds.), 227-34.

Mallowan, M.E.L. \& J.C. Rose, 1935. Excavations at Tell Arpachiyah, 1933. Iraq 2, 1-178.

Manning, A. \& J. Serpell (eds.), 1994. Animals and Human Society. London: Routledge.

Mellaart, J., 1967. Çatal Hüyük: a Neolithic Town in Eastern Anatolia. London: Thames \& Hudson.

Mellink, M.J. \& J. Filip, 1974. Frühe Stufen der Kunst. (Propyläen Kunstgeschichte 13.) Berlin: Propyläen.

Midant-Reynes, B., 1992. Préhistoire de l'Egypte: Des Premiers Hommes aux Premiers Pharaons. Paris: Armand Colin.

Midant-Reynes, B., N. Buchez, E. Crebézy \& T. Janin, 1996. The predynastic site of Adaima: settlement and cemetery, in Aspects of Early Egypt, ed. A.J. Spencer. London: British Museum, 93-7.

Millet, N.B., 1990. The Narmer Macehead and related objects. Journal of the American Research Center in Egypt $27,53-9$. 
Mond, R. \& O.H. Myers, 1937. Cemeteries of Armant I (two volumes). London: Egypt Exploration Society.

Morgan, L.H., 1877. Ancient Society: Researches in the Lines of Human Progress from Savagery, through Barbarism to Civilization. London: Macmillan.

Morris, D., 1985. The Art of Ancient Cyprus: with a Check-list of the Author's Collection. Oxford: Phaidon (in association with Cape.)

Murray, M.A., 1956. Burial customs and beliefs in the hereafter in Predynastic Egypt. Journal of Egyptian Archaeology 42, 86-96.

Needler, W., 1984. Predynastic and Archaic Egypt in the Brooklyn Museum. New York (NY): The Brooklyn Museum.

Okely, J. \& H. Callaway, 1992. Anthropology and Autobiography. (ASA Monograph 29.) London: Routledge.

Paddaya, K., 1973. Investigations into the Neolithic Culture of the Shorapur Doab, South India. Leiden (NY): E.J. Brill.

Payne, J.C., 1993. Catalogue of the Predynastic Egyptian Collection in the Ashmolean Museum. Oxford: Clarendon Press.

Petrie, W.M.F., 1901. Diospolis Parva: the Cemeteries of Abadiyeh and Hu 1898-9. London: Egypt Exploration Fund.

Petrie, W.M.F., 1920. Prehistoric Egypt. London: British School of Archaeology in Egypt \& Bernard Quaritch.

Petrie, W.M.F., 1921. Corpus of Prehistoric Pottery and Palettes. London: British School of Archaeology in Egypt; Constable; Bernard Quaritch.

Petrie, W.M.F., 1953. Ceremonial Slate Palettes and Corpus of Predynastic Pottery. London: Egyptian Research Account.

Petrie, W.M.F. \& J.E. Quibell, 1896. Naqada and Ballas 1895. (British School of Archaeology in Egypt and Egyptian Research Account 1.) London: Bernard Quaritch.

Petrie, W.M.F., G.A. Wainwright \& E. Mackay, 1912. The Labyrinth, Gerzeh, and Mazghuneh. London: School of Archaeology in Egypt \& Bernard Quaritch.

Quibell, J.E., 1898. Slate palette from Hieraconpolis. Zeitschrift für Ägyptische Sprache 36, 81-6.

Quibell, J.E., 1904-5. Archaic Objects. (Catalogue Général des Antiquités Égyptiennes du Musée du Caire.) Cairo: Impr. de l'Institut Français d'Archaéologie Orientale.

Randall-MacIver, D. \& A.C. Mace, 1902. El Amrah and Abydos 1899-1901. (Egypt Exploration Fund Memoirs 23.) London: Egypt Exploration Fund.

Reinold, J., 1987. Les fouilles pré- et proto-historiques de la Section Française de la Direction des Antiquités du Soudan: les campagnes 1984-85 et 1985-86. Archeologie du Nil Moyen 2, 17-60.

Reinold, J., 1991. Néolithique Soudanais: Les Coutumes Funéraires, in Davies (ed.), 16-29.

Reisner, G.A., 1910. Archaeological Survey of Nubia: Report for 1907-1908. Cairo: Ministry of Finance, Survey Department.

Resch, W.F.E., 1967. Die Felsbilder Nubiens. Graz: Akademische Druck- und Verlagsanstalt.
Rice, M., 1998. The Power of the Bull. London: Routledge.

Robertson Smith, W., 1889. Lectures on the Religion of the Semites. Edinburgh: Black.

Robins, G., 1994. Proportion and Style in Ancient Egyptian Art. London: Thames \& Hudson.

Scamuzzi, E., 1965. Egyptian Art in the Egyptian Museum of Turin. New York (NY): Harry N. Abrams Inc.

Scharff, A., 1926. Die archäologischen Ergebnisse des vorgeschichtlichen Gräberfeldes von Abusir el-Meleq. Leipzig: Hinrichs.

Scharff, A., 1929. Die Altertümer der Vor- und Frühzeit. Staatliche Museen zu Berlin, Mitteilungen aus der Ägyptischen Sammlung V. Berlin: Karl Curtis.

Schmidt, P.W., 1940. Der Ursprung der Gottesidee VII: die Afrikanischen Hirtenö̈lker - Hamiten und Hamitoiden. Münster: Aschendorff.

Schwabe, C., 1994. Animals in the ancient world, in Manning \& Serpell (eds.), 36-58.

Seligman, C.G., 1914. Some Aspects of the Hamitic Problem in the Anglo-Egyptian Sudan. London: Royal Anthropological Institute of Great Britain and Ireland.

Seligman, C.G., 1932. Pagan Tribes of the Nilotic Sudan. London: Routledge.

Seligman, C.G., 1934. Egypt and Negro Africa: a Study in Divine Kingship. London: Routledge.

Sethe, K., 1930. Urgeschichte und älteste Religion der Ägypter. (Abhandlung für die Kunde des Morgenlandes 18(4).) Leipzig: Deutsche morgenländische Gesellschaft.

Sherratt, A., 1997. Troy, Maikop, Altyn Depe: Early Bronze Age urbanism and its periphery, in Economy and Society in Prehistoric Europe: Changing Perspectives, ed. A. Sherratt. Edinburgh: Edinburgh University Press.

Smith, H.S., 1991. The development of the 'A-Group' culture in Northern Lower Nubia, in Davies (ed.), 92111.

Smith, H.S., 1992. The making of Egypt: a review of the influence of Susa and Sumer on Upper Egypt and Lower Nubia in the 4th millennium BC, in Friedman \& Adams, 235-46.

Strathern, A., 1971. The Rope of Moka: Big Men and Ceremonial Exchange in Mount Hagen, New Guinea. Cambridge: Cambridge University Press.

Tapper, R., 1979. Pasture and Politics: Economics, Conflict, and Ritual among Shahsevan Nomads of Northwestern Iran. London: Academic Press.

Todd, I.A., 1978. Çatal Hüyük in Perspective. Menlo Park: Cummings.

Trigger, B., 1983. The rise of Egyptian Civilization, in $A n-$ cient Egypt: a Social History, by B.G. Trigger et al. Cambridge: Cambridge University Press, 1-70.

Ucko, P.J., 1969. Ethnography and archaeological interpretation of funerary remains. World Archaeology 1(2), 262-80.

Ucko, P.J. \& H.W.M. Hodges, 1963. Some Predynastic Egyptian figurines: problems of authenticity. Journal of the Warburg and Courtauld Institutes 26, 205-22.

von Oppenheim, M.F., 1943. Tell Halaf. Erster Band: die prähistorischen Funde. Berlin: Walter de Gruyter. 
Walker, A.R., 1986. The Toda of South India: a New Look. Delhi: Hindustan Publishing Corporation.

Watkins, T., 1996. The origins of the household in north Mesopotamia, in Houses and Households in Ancient Mesopotamia, ed. K.R. Veenhof. (Uitgaven van het Nederlands Historisch-Archaeologisch Instituut te Istanbul 78.) Istanbul: Nederlands HistorischArchaeologisch Instituut te Istanbul.

Wendorf, F. \& R. Schild, 1998. Nabta Playa and its role in northeastern African prehistory. Journal of Anthropological Archaeology 17(2), 97-123.

Wengrow, D., 1998. 'The changing face of clay': continuity and change in the transition from village to urban life in the Near East. Antiquity 72, 783-95.

Wengrow, D., 1999. The intellectual adventure of Henri Frankfort: a missing chapter in the history of archaeological thought. American Journal of Archaeology 103, 597-613.

Wetterstrom, W., 1993. Foraging and farming in Egypt: the transition from hunting and gathering to horticulture in the Nile Valley, in The Archaeology of Africa: Food, Metals and Towns, eds. T. Shaw et al. (One World Archaeology Series 20.) London: Routledge, 165-226.

Wilkinson, T.A.H., 1999. Early Dynastic Egypt. London: Routledge.

Williams, B., 1986. The A-group Royal Cemetery at Qustul: Cemetery L. Excavations between Abu Simbel and the Sudan frontier 1. Chicago (IL): Oriental Institute of the University of Chicago.

Williams, B., 1988. Decorated Pottery and the Art of Naqada III: a Documentary Essay. (Münchner Ägyptologische Studien 45.) Munich: Deutscher Kunstverlag.

Winter, E., 1994. Wer steht hinter Narmer?, in Zwischen den beiden Ewigkeiten. Festschrift Gertrud Thausing, eds. M. Bietak, J. Holaubek, H. Mukarovsky \& H. Satzinger. Vienna: Eigenverlag des Institutes für Ägyptologie der Universität Wien, 279-90. 